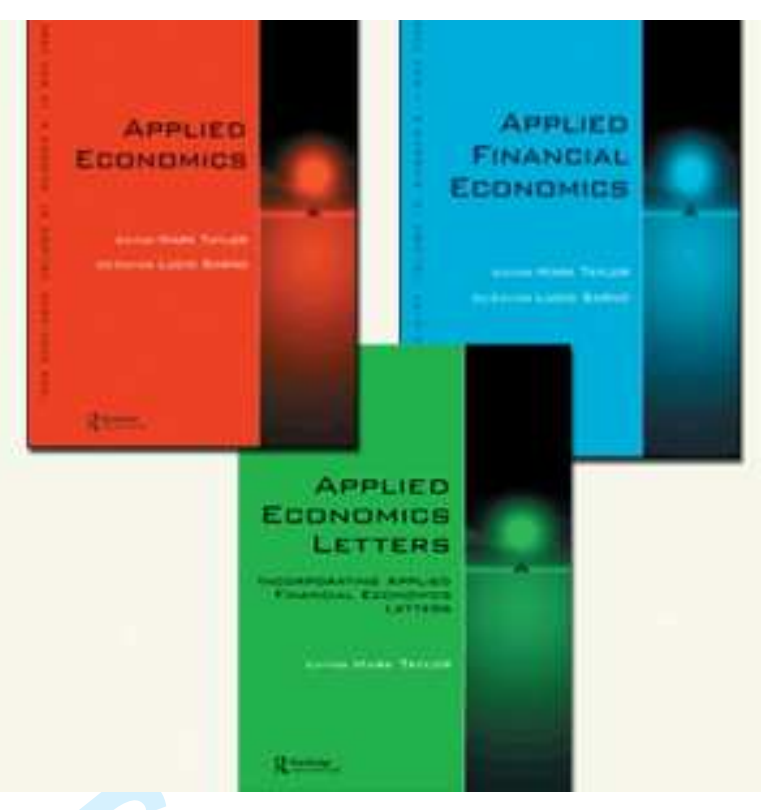

\title{
ASSESSING THE IMPACT OF LOCAL TAXATION ON PROPERTY PRICES: A SPATIAL MATCHING CONTRIBUTION
}

\begin{tabular}{|r|l|}
\hline Journal: & Applied Economics \\
\hline Manuscript ID: & APE-2011-0102 \\
\hline Journal Selection: & Applied Economics \\
\hline Date Submitted by the & O2-Mar-2011 \\
\hline Complete List of Authors: & $\begin{array}{l}\text { Charlot, Sylvie; INRA, GAEL } \\
\text { Paty, Sonia; CREM (University of Caen and CNRS) and EQUIPPE } \\
\text { (Universities of Lille) } \\
\text { Visalli, Michel; INRA, UMR CSGA (1324) }\end{array}$ \\
\hline JEL Code: & $\begin{array}{l}\text { H30 - General < H3 - Fiscal Policies and Behavior of Economic } \\
\text { Analysis < R - Urban, Rural, and Regional Economics }\end{array}$ \\
\hline Keywords: & \begin{tabular}{l} 
fiscal capitalization, local taxation, property prices, borders \\
\hline
\end{tabular} \\
\hline
\end{tabular}

\section{SCHOLARONE \\ Manuscripts}




\section{Introduction}

Issues surrounding the impact of local taxation and public services are the key concern in a wide literature based on Tiebout (1956) which shows that individuals reveal their preferences by "voting with their feet." If citizens are faced with choosing among several communities that offer different types or levels of public goods and services, then they will choose the community that best satisfies their own individual requirements. Citizens needed high levels of public goods will be concentrated in communities with high levels of public services and high taxes, while those with low level demand will tend to choose other communities with lower levels of public services and lower taxes. If households were perfectly mobile, Tiebout (1956) argues that an efficient pattern of local services would be attained without the intervention of a central government. However, Tiebout's argument does not cope with property tax or capitalization. Later analyses combined the introduction of a property tax with Tiebout's key assumptions (perfect mobility across jurisdictions, complete information, multiple jurisdictions). On the one hand, Oates (1969) and Brueckner (1979) argue that capitalization exists when lower property taxes or better local public services lead to higher house values. On the other hand, Edel and Sclar (1974), Hamilton (1975), and Epple, Zelenitz and Visscher (1978) focus on supply responses to rent differentials and predict the disappearance of this capitalization (see Yinger (1982) and Starret (1981) who discuss the validity of land capitalization). 
Following Oates $(1969,1973)$, numerous empirical analyses have addressed capitalization of interjurisdictional fiscal differentials. From this large literature, Cushing (1984) was the first to consider that if capitalization of interjurisdictional fiscal differentials occurs, it should be most obvious at the border between two jurisdictions. He and others (Black, 1999; Gibbons and Machin, 2003, 2006; Kane, Riegg and Staiger, 2006; Fack and Grenet, 2010) use housing price differentials between adjacent blocks at the border of two jurisdictions to study capitalization. This 'geographical boundary' approach has also been applied in models examining the effects of cross boundary differences in taxation on employment growth (Duranton, Gobillon and Overman, 2007).

This paper is aimed at providing empirical evidence on the impact of local taxation on property prices, using the geographical boundary method and applying it to the French context. We focus on the local property tax that applies to buildings and is based on the property's theoretical rental value. The impact of this tax rate on property prices has been the subject of numerous debates in France (Mercier, 2000) since the theoretical values estimated by the French administrations is often very different from the actual property values. ${ }^{1}$

The main contribution of the paper is to apply a more rigorous spatial matching and differencing strategy to the taxation/expenditure question. We use data on individual housing which are available for two French urban areas (Dijon and Besançon) for about 10,000 house sales, for the period 1994 to 2004. Our empirical methodology pairs transactions to estimate the impact of property taxation on prices. After identifying transactions close to the jurisdiction borders, we can control for housing characteristics to isolate time-varying local property taxes. Spatial differencing and instrumental variables (IV) methods allow us to compare sales and to control for the endogeneity of local taxation. 
Our results suggest that the local property tax rate does not have the expected impact on property price levels. However, when it is crossed with variables used to evaluate the base, it has a significant and negative effect when the base proxy is large. We can conclude that buyers are more sensitive to the amount of taxes they will have to pay than to the tax rate. This is logical, since in France local property bases vary substantively.

The paper is organized as follows. Section II provides a short review of the literature on fiscal capitalization. Section III presents the data and summary statistics. The methodology is described in Section IV and the main results are contained in Section V. Section VI presents some robustness checks and section VII concludes.

\section{Literature review}

We describe the theoretical background and the econometric issues associated with the estimation of hedonic models.

\subsection{Theoretical background}

We use the simple model of Yinger (1982) to introduce the capitalization of property rate into house value. Households are assumed to be similar. When choosing a residential location, we assume that a household considers the property tax rate, $t$, and the level of local public services per household, $G$, in each jurisdiction. The amount a household is willing to pay for one unit of housing services depends on the supply of public goods and the tax rate that apply to a jurisdiction. As a consequence, the bid function for one unit of housing is given by: $P=P(G, t)$. Assuming that a house contains $H$ units of housing services, the value of the house to the household may be given by: $V(G, t)=P(G, t) H / r$ where $r$ is the discount rate. 
Each household has to pay a property tax that is proportional to the value of the house, i.e. $t P(G, t) H / r$. The household's income $Y$ is used to buy a composite consumption good $X$ whose price is unitary, housing services in quantity $H$ at price $P$ and property taxes at rate $t$. The maximization problem for the household is as follows:

$$
\begin{gathered}
\max _{Z, H, G, t} U(X, H, G) \\
\text { s.t. } Y=X+P(G, t) H[1+t / r]
\end{gathered}
$$

To describe the effect of property tax on house values for a given level of public services $G^{*}$, we must solve the following equation given by one first-order condition:

$$
\frac{\partial Y}{\partial t}=\frac{\partial P}{\partial t} H[1+t / r]+P\left(\frac{H}{r}\right)=\frac{\partial P}{\partial t}(r+t)+P=P^{\prime}(r+t)+P=0
$$

with $P^{\prime}=\frac{\partial P}{\partial t}$. The solution for this differential equation (1) can be written as:

$$
P\left(G^{*}, t\right)=P^{\prime} H /(r+t)
$$

Combining this solution into the equation for house value, we can derive the capitalization of property tax rate into house values for a given level of public services:

$$
V\left(G^{*}, t\right)=P\left(G^{*}, t\right) H / r=P^{\prime} H /(r+t)
$$

If we let the level of public goods supply vary, equation (2) becomes:

$$
P(G, t)=r P^{\prime}(G) /(r+t)
$$

where $P^{\prime}(G)$ describes each household's bid for housing services before tax, i.e. for $t=0$.

To determine the form of $P^{\prime}(G)$, we have to compute the housing demand $H$. We thus have to specify the utility function. Choosing a Cobb-Douglas utility function, we get: 


$$
U(X, H, G)=\alpha \ln (X)+\beta \ln (H)+\gamma \ln (G)
$$

The household's bid function is for every pair $(G, t)$ :

$$
P(G, t)=\frac{C r G^{\frac{\gamma}{\beta}}}{r+t}
$$

where $\mathrm{C}$ is a constant of integration. If we assume that housing services are a multiplicative function of housing characteristics, $Z_{1}$ to $Z_{n}$, the value of a house becomes:

$$
V(G, t)=P(G, t) H / r=\left(\frac{C r G^{\frac{\gamma}{\beta}}}{r+t}\right) \prod_{i=1}^{n} Z_{i}^{a_{i}}
$$

or

$$
\ln (V)=\ln (C)+\frac{\gamma}{\beta} \ln (G)-\ln (r+t)+\sum_{i=1}^{n} a_{i} \ln \left(Z_{i}\right)
$$

This relationship (4) describes how the value of a house capitalizes for a given discount rate $r$, public services $G$ weighted by their preferences $\frac{\gamma}{\beta}$, property tax $t$ and the housing characteristics. Yinger's definition of capitalization when households are assumed to be similar is thus the following. Local fiscal variables are completely capitalized into house values when the variation in house values within or between the jurisdictions exactly reflects what households are willing to pay for the different public goods-tax couplings in different locations.

\subsection{The empirical tests}

Let us turn now to the empirical estimation of the resulting model which is called the traditional hedonic specification:

$$
V=c+\zeta G-\tau t+\sum_{i=1}^{n} a_{i} Z_{i}+\eta N+\varepsilon
$$


where $N$ are neighborhood characteristics and $\varepsilon$ is a vector of i.i.d. error terms.

There are numerous empirical analyses of capitalization of interjurisdictional fiscal differentials. Oates's $(1969,1973)$ seminal papers found significant capitalization of public services and almost complete capitalization of property tax rate differentials for a sample of cities in the state of New Jersey. Follain and Malpezzi (1981), on the other hand, concluded that fiscal surplus, i.e. public service expenditures minus taxes per capita, differentials were not capitalized into house values. Other studies have produced diverse results (see e.g. Edel and Sclar, 1974; King, 1977; Rosen and Fullerton, 1977; Wales and Wiens, 1974; Sonstelie and Portney, 1980; Chaudry-Shah, 1989, etc.)

An important consideration is how locational effects, positive as well as negative, are capitalized into house values. Can (1992) distinguishes between two levels of externalities. The first captures the neighborhood effects, i.e. the impact of common neighborhood characteristics on housing prices. The second level includes spatial spill-over effects adjacency effects - such as the impact of the prices of neighboring structures. These effects are not confined to jurisdictions, they can cross boundaries. As argued by Can (1992), locational effects require the use of different specifications for the housing price equation (see details in the appendix A). We need to test for spatial effects to detect the existence of spatial dependence and/or spatial heterogeneity and to choose the right specification.

To circumvent the problems associated with spatial effects, we use an alternative methodology, first implemented by Cushing (1984) and developed by Black (1999) to test the theoretical prediction that housing prices are influenced by the quality of schools. ${ }^{2}$ The main estimation problem is that measuring the effects of school quality on housing prices raises an 
endogeneity problem since better schools tend to be located in wealthier neighborhoods because of the higher performance of children from more privileged families. Black (1999) suggested comparing the prices of houses located on opposite sides of a common elementary school district boundary. She assumes that changes in school quality are discrete at the boundaries, whereas changes in neighborhood characteristics are smooth. She goes on to relate the differences in mean prices of houses located at opposite sides of attendance district boundaries, to performance in school examinations. Then, houses differ only in terms of elementary schools. Her sample is based on a selection of the sales located within 0.15 mile of a boundary. She finds that parents are willing to pay $2.5 \%$ more in house prices for a $5 \%$ increase in test scores. In our paper, we will apply this geographical boundary approach to our taxation/expenditure issue.

Gibbons and Machin $(2003,2006)$ also use this method to explain school choice. To do so, they build a hedonic property price model. It is well known that the difficulty of this approach is to specify what to include in the hedonic price function since neighborhood composition is endogenous in a property value model. To circumvent the problem of simultaneity between property prices and performance, they used instrumental variables (IV) method for school performance. They isolate schools characteristics - historically determined school-type characteristics - that influenced performance but were not affected by local property prices or neighborhood socio-economic status. They exploited the co-variation in house prices and school performance within narrowly defined spatial groups and computed spatially weighted means for the variables in their model at each observation, whereby the nearest observation receives the highest weight. They find that a percentage point increase in the neighborhood proportion of children reaching the government-specified target grade pushed up neighborhood property prices by $0.67 \%$. Following Gibbons and Machin (2003, 2006), we 
will use IV to circumvent the problem of simultaneity between property prices and taxation (or expenditure). In our case, this problem is due to the Tiebout sorting effect that implies that richer people have a preference for more public services.

The paper by Fack and Grenet (2010) provides empirical evidence on the impact of middle school quality on housing prices in Paris, using data on both school zoning and real estate transactions over the period 1997-2003. Building on geographical boundary approach, they use a matching framework to compare sales across school attendance district boundaries and to deal with the endogeneity of school quality. They compare each transaction with a constructed counterfactual transaction. This fictive counterfactual sale is supposed to be a measure (all else being equal) of the amount involved in a reference sale if the property were located in another school zone. The price of the counterfactual transaction is computed as the weighted geometric mean of the prices of all transactions that took place in the same neighborhood but in a different school zone. Their estimates are similar to those found in US and UK studies (Black, 1999; Gibbons and Machin, 2003, 2006): a standard deviation increase in school quality raises prices by about $2 \%$.

As Fack and Grenet (2010), we will build some counterfactual sales to study the effect of taxation and expenditure on transactions. Their methodology is very useful for our question since we are interested in what happens on each size of a border, the municipal border. However, we will improve this methodology in the way we use density to build the counterfactual variables. This choice is explained in the methodology section.

\footnotetext{
Although their study is of the impact of local taxation on employment growth and not the influence of school quality on housing prices, the methodology used by Duranton, Gobillon
} 


\section{Data and summary statistics}

In this section, we present the data. Since data are transactions and therefore do not constitute panel data, the methodology used here is closer to that in Fack and Grenet (2010) than to the methodology employed by Duranton, Gobillon and Overman (2007).

\subsection{Housing prices}

Our data on property sales come from Perval, which was created by the Notary Chambers in France - all property sales are registered with Notary offices. For each transaction, we have information on the sale price of the property (see figure 1), along with details of features such as size, number of rooms, date of construction, etc. and precise geographical location. The geographical precision of geocoded data, i.e. Lambert grid coordinates, is about 10 meters. Our sample is restricted to house sales in two urban areas (Dijon and Besançon) between 1994 and 2004, giving a sample of around 10,000 transactions. It should be noted that value added tax on real estate is payable by the seller for a property sold in the first 5 years after its construction. This is charged at the rate of $19.60 \%$ of the selling price. We include this tax as an explanatory variable.

[Figure 1 about here] 


\subsection{French local taxation}

France is usually considered as unitary in terms of government although different layers of local governments have wide fiscal autonomy. The structure of local government is broadly four tiered. The lowest tiers consist of 36,600 municipalities and 13,000 groups of municipalities. The third tier consists of 96 departments and the top tier is the 22 regions that are at the highest level of local government. Local revenue sources derive mainly from local taxes (54\%), central government grants (23\%) and borrowing (10\%). Each level of local government sets its own tax rates, on a common tax base, for a large range of local direct taxes, which account for $75 \%$ of local tax revenues.

Local authorities have considerable latitude in the tax rates for these four types of taxation. ${ }^{3}$ The "local tax varying power" is the proportion of local resources represented by tax revenue, over which local authorities have some control; France has the second highest level of tax autonomy (54\%) in the European Union, compared with $20 \%$ in Germany which is a federal country, and Spain (35\%) which is close to being a federal country, and the UK at $14 \%$. Furthermore, the degree of tax revenue decentralization computed as the ratio between subnational government own tax revenue over consolidated general government total tax revenue is equal to $18.4 \%$ in France over the period 1999-2001, while it on average $14 \%$ in the EU-15 over the same period (see Stegarescu (2000) using the OECD (1999) categories of tax autonomy). Vertical imbalance is the degree to which subnational governments rely on central government revenues to support their expenditure and is likely to increase the size of the public sector when the expenditure responsibilities of sub-national governments do not match their revenue raising power. This indicator - measured by intergovernmental transfers as a share of subnational expenditures - was of 34.9 per cent in France in 1972-2004 but was higher in the EU-15 at 43.7 per cent for the same period (Source: International Monetary 
Fund).

There are two local taxes that are based on theoretical rental value according to the local land registry. Property tax is payable by the owner, while housing tax is payable by the occupier. Property tax is made up of two different tax rates that apply respectively to the buildings and to the land belonging to the property. Tax rate is set within jurisdiction but as tax base is different for each property, the amount of taxes that owners or occupiers have to pay is different.

New buildings and renovations are exempt from tax for two years. Taxes are also not applicable to buildings used for agricultural purposes or if the premises are used exclusively for farming, business or student lodgings. People aged over 75 and those with disability pensions are also exempt from property/housing tax and discounts are available for some people over 65 on low incomes.

The local business tax (the so-called Taxe Professionnelle) is the major source of tax revenue for local governments since it accounts for approximately $45 \%$ of the revenue from direct local taxation. Its tax base is mainly capital goods and it is calculated on the rental value of the buildings and the equipment.

There is an institutional rule in France that ties the increase in local business tax rates to the increase in household taxes (property and housing tax rates). A jurisdiction cannot set a higher (lower) tax rate for business if it has not increased (decreased) its housing tax rates. Consequently, the relationship between the local business tax rate and the housing tax rate is often complementary (Charlot and Paty, 2007). Although collected centrally these taxes are 
distributed to local jurisdictions and are used to finance local public services, such as rubbish collection, street cleaning, schools and other community facilities, as well as the administration of these services.

We focus on the property tax (PT) rate that applies to buildings and is based on the theoretical rental value of the property. ${ }^{4}$ The impact of this tax rate on property prices has been much debated in France (Mercier, 2000). Since the last major updating of property bases in 1970, theoretical property values often differ widely from actual values.

As we are interested in local tax variations, where applicable, the municipal tax rate is added to the tax rates of the group of municipalities. ${ }^{5}$ Fiscal data are from the Direction Générale des Collectivités Locales (DGCL, Ministère de l'Intérieur).

[Figure 2 about here]

Figure 2 shows that the evolution of property prices more or less matches the evolution of property tax rates. Table 1 provides some descriptive statistics for each fiscal variable.

[Table 1 about here]

Maps 1 and 2 show that property tax rate and mean property price are spatially correlated. Both increase with a decrease in the distance from the city center. This can be explained in various of ways. Both variables are strongly correlated to urban amenities and access to employment. The significant relationship between these variables therefore may have little to do with land capitalization but may be due to the location of the property. 
[Map 1 and Map 2 about here]

\section{Methodology}

In order to estimate the impact of local taxation on property values, we estimate a "spatial difference" model similar to that of Fack and Grenet (2010). Their methodology is adapted to take account of the variability in density of large urban areas. In a first step prices are estimated by a classical hedonic regression with individual characteristics only. Then the estimated price is transformed and regressed on municipal variables. The transformation is a spatial difference to control for the location specific effect, measuring all neighborhood effects including local amenities (distance to the city center, access to infrastructure,...) and spatial interactions between transactions. This methodology is aimed at comparing each individual transaction to any other transaction located close by, and therefore within the same neighborhood. Each transaction is matched with a counterfactual sale constructed with other very close transactions.

This is a two-step estimation. In the first step, the house price is assumed to depend on its individual characteristics.

$$
\ln p_{i, m, t}=\alpha+\sum_{i} \beta_{i} X_{i}+\varepsilon_{i, m, t}
$$

where $X_{i}$ is the vector of property's characteristics. This regression leads to an estimated price of the house that gives the mean price that the house would be sold taking into account its own characteristics. 


$$
\widehat{\ln p_{\mathrm{m} m \mathrm{t}}}=\ln p_{\mathrm{im}, \mathrm{t}}-\varepsilon_{\mathrm{i} m \mathrm{~m}, \mathrm{t}}
$$

Once individual characteristics are controlled, we focus on the price of access to a specific neighborhood and to specific municipality facilities. The price of houses, located in neighborhood $n$, in municipality $m$ and sold at time $t$, is assumed to be a sum of a neighborhood fixed effect, a municipal fixed effect, a time fixed effect and an error term, $\varepsilon_{n, m, t}:$

$$
\widehat{\ln } \widehat{p_{n, m, t}}=\Psi_{n}+\Psi_{m}+\Psi_{t}+\varepsilon_{n, m, t}
$$

The different fixed effects are assumed not to be correlated to each other and uncorrelated with the error term.

If one transaction that takes place in one municipality, $m_{1}$, were to be transposed to another, $m_{2}$, but within the same neighborhood, and the same year, the difference in the fixed effects combination would only be $\Psi_{m}$. If the time and the neighborhood fixed effects disappear $\Psi_{m}$ can be identified. In order to do so, for each sale we compute a counterfactual sale, which evaluates the price of the house if it were sold at the same time and in the same neighborhood but in another municipality. Under these assumptions, we write:

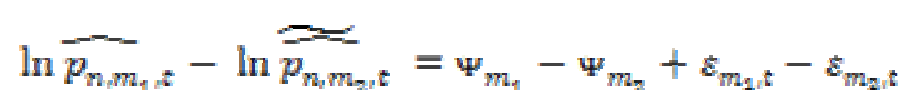


The municipal fixed effect is assumed to be a linear function of the log of the local tax rate in the year of the transaction, $\tau_{m}$, municipal public spending per capita, $P S_{m}$, and an error term, $\delta_{m}:$

$$
\Psi_{m}=\gamma+\rho \ln P S_{m}+\pi \ln \tau_{m}+\delta_{m}
$$

Municipal public spending is introduced to proxy for the quantity of public services provided locally. The composition of municipal public spending is as follows: street lighting, roads, water supply, kindergartens, ancillary activities for primary schools (canteens, extracurricular activities...). They vary hugely among municipalities: they are equal to 444,690 thousands Euros on average, with a standard error equals to 616,167 .

Introducing (9) in (7) leads to:

$\ln \overline{p_{n, m, t}}=\Psi_{n}+\Psi_{z}+\gamma+\rho \ln P S_{m}+\pi \ln \tau_{m}+\delta_{m, t}$

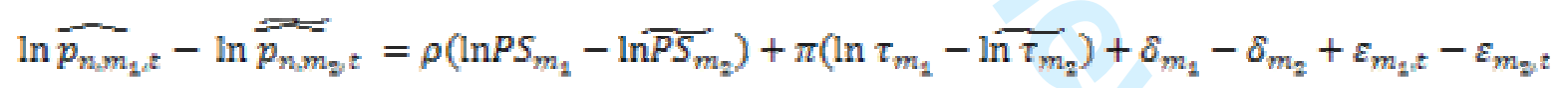

where $\ln p_{n_{n} m_{n, t}}$ is the estimated price of the counterfactual. The measurement error induced by the estimation of the counterfactual sale price only affects the dependent variable and hence will not bias the estimation of $\rho$ and $\pi$.

In order to consider that the neighborhood remains the same, the counterfactual estimated price and municipal characteristics are the weighted mean of these variables of all the transactions occurring within a certain distance, and in the same year. For each variable $Z_{i}$ 
characterizing the transaction $i$ (estimated price, tax rate and local public spending), we calculate the counterfactual variable using the following transformation:

$$
\widetilde{Z_{i}}=\frac{1}{\sum_{j} \frac{1}{d_{i, j}}} \sum_{j} \frac{1}{d_{i, j}} Z_{j}
$$

where $j$ are all the transactions that take place within the defined distance from transaction $i$ occurring in the same year. $d_{i, j}$ is the euclidean distance between $i$ and $j$.

We now describe the criterion used to decide which transactions $j$ are chosen to build the counterfactual variables and therefore to set the maximum distance under which the neighborhood can be considered as identical. Our data apply to large urban areas, including urban and suburban environments where the latter is less dense. In order to examine whether access to local amenities is more sensitive to distance in very dense contexts than in less dense ones, and in order not to give too much weight to urban transactions, we chose a maximum distance that depends on municipal population density, for each transaction. We therefore built our counterfactuals by considering all transactions within the distance threshold from $i, \bar{d}$, defined by:

$$
\bar{d}=\frac{d_{\min }}{\left(\left(\text { density } \text { mun }_{i}+\text { density } \text { mun }_{j}\right) / 2\right) / \text { density city center }}
$$

where density mun $_{i}$ and density mun $_{j}$ are the population density in the municipality where transaction $i$ and transaction $j$ take place. density city center, the density of the city center, is introduced in order to take account of the fact that our observations are localized in two different urban areas: Dijon and Besançon. $d_{\min }$ is introduced for transactions in the city 


\begin{abstract}
center, since otherwise $\bar{d}$ would be equal to 1 . We also set a $d_{\max }$, for transactions that occur in less dense municipalities. The larger $d_{\min }$, the greater the weight given to the transactions occurring in the denser municipalities, i. e. close to the city center. Conversely, the larger $d_{\max }$, the greater the weight given to less dense municipalities.
\end{abstract}

Finally, all transactions $j$ from a distance smaller than $\bar{d}$ of transactions $i$, occurring in the same year, are used to calculate the counterfactual characteristics. It allows controlling for constant spatial variables as well as time changes.

\title{
5. Results
}

To control for the impact of the distance threshold, we estimate the second step equation (10) for two different counterfactuals, depending on the maximum threshold distance; in the first case $d_{\max }$ is equal to 1,000 and in the second case equal to 2,000 meters. In the second case there are more transactions in the suburbs in the data. In order not to give too much weight to the more centrally located transactions, the $d_{\min }$ is quite small and always the same: 200 meters. The maps below show the transactions for which we were able to build a counterfactual, with $d_{\max }=2,000$.

[Map 3 and Map 4 about here]

[Table 2 about here]

As we want to focus on fiscal land capitalization, and since owners do not pay the housing tax 
if they do not occupy the accommodation, we only estimate the impact of property tax on transactions price. Summary statistics on property tax rates are presented in Table 2. The average property tax rate depends on the urban area and the distance threshold. Higher average values are observed for Dijon and when no distance threshold is applied. When more transactions in the suburbs are introduced, the average property tax rate takes a lower value, about $13.4 \%$ with a standard deviation of 4.4 . In our view, we have sufficient variation to perform our estimations for both thresholds.

In the first step we estimate the classical hedonic regression, in order to control for house characteristics:

$$
\ln p_{i, m, t}=\alpha+\beta_{1} S_{i}+\beta_{2} \text { Room }_{i}+\beta_{3} G S_{i}+\beta_{4} \text { Tconst }_{i}+\beta_{5} V A T+\beta_{6} T_{i}+\varepsilon_{i, m, t}
$$

where $p_{i, m, t}$ is the price per square meter of the housing good $i$, observed in the municipality $m$ at period $t . S_{i}$ is the living space of the housing good and $G S_{i}$ is the size of the garden weighted by the living space, which takes the value zero when there is no garden. Room $_{i}$ is the number of rooms weighted by the living space. Tconst ${ }_{i}$ is a set of dummies defining the date when $i$ was built; Tconst 1 takes the value 1 when the property was built before 1850 , Tconst 2 when it was built between 1850 and 1913, Tconst 3 between 1914 and 1947 , Tconst 4 between 1948 and 1969, Tconst 5 between 1970 and 1980, Tconst 6 between 1981 and 1991. Tconst 7 takes the value 1 when the property was built after 1992 and was not new at the time of the transaction, Tconst 8 takes the value 1 when the property was built after 1992 and was new when the transaction occurred. $V A T_{i}$ is the value added tax on real estate. The value added tax rate is different for houses of different ages: for new one it is zero, for home built within the last 5 years it is a small (5.09\%) and older homes are levied at the full rate $(19.6 \%)$. It is therefore to introduce it as a control variable. We also introduced a trend 
variable $\left(T_{i}\right)$ in order to control for the global evolution of the housing market. Table 3 shows the results for the first step regression.

[Table 3 about here]

We first see (column 1) that the size of the property tax has a negative impact on the sale price (per square meter) and no impact when the distance threshold is extended to 2,000 meters. The room number weighted by the property size has a positive coefficient suggesting that this characteristic increases the sale price. We obtained significant coefficients for the date of construction showing that older properties are less expensive than more recently built ones. Finally, the real estate value added tax has a negative impact on lodging prices.

In the second step we estimate the equation (10), relating spatial differences in estimated price to spatial differences in municipal public policy variables:

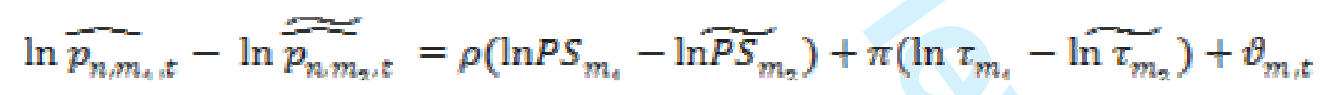

Results of equation (10) estimated by OLS are given in Table $4^{6}$.

[Table 4 about here]

First, local public policy, in terms of property tax rate and operating public spending, does not explain any variance (or very little) in the price per square meter in our French data. The coefficient associated with local public spending per capita is never significant. Even when 
controlling for the operating public spending, the property tax rate has no or a barely significant effect on property prices, once the effects of the local environment are controlled for using the spatial differences methodology. When transactions used in estimates are less concentrated in the denser areas, the elasticity of property price to the tax rate is almost $5 \%$. Moreover, this coefficient is only significant at $10 \%$. These results, which are very similar when the maximum distance is equal to 1,500 meters, suggest that neither property tax nor operating public spending have effect on property prices.

\section{Robustness checks \\ 6.1. Tax base effects}

Since in France, the property tax base may be disconnected from the price of the transaction, the amount of tax paid by owners of two houses with the same characteristics and costing the same can vary. We try to proxy for this tax base in order to control for its effect on the transaction price. We do not have data that include the base of the property tax which is different for each transaction and is correlated to the characteristics of the house and also with its age; the tax base of old buildings has not been reassessed since 1970. With the same features (size...), the tax base of an older house therefore is smaller than the tax base of a new one. Thus the tax value paid by the owner is also smaller. The house buyer is more sensitive to the tax she or he will have to pay than to the tax rate.

The value of newly constructed homes is assessed accurately during the year of construction. However, these values are not subsequently updated. The value of recent constructions is closer to the actual value than the values assigned to older ones. In order to take this effect into account we introduce a variable interacting size, time of construction and tax rate rather than tax rate alone. 
In the second step, the equation becomes the following:

$$
\begin{aligned}
& \ln \widehat{p_{\mathrm{b}, m, \varepsilon}}-\ln \widehat{\tilde{p}_{\mathrm{b}, m, \varepsilon}}=\rho_{m}\left(P S_{i, m}-\widehat{P S_{i, m}}\right)+\pi\left(\ln \tau_{i, m, \varepsilon}-\ln \tilde{\tau}_{i, m, \varepsilon}\right) \\
& +\varphi\left(S_{i} \times T_{\text {const }_{i}} \times \tau_{i_{i} m, z}-S_{i} \times \widetilde{T_{\text {const }}} \times \tau_{i, m, t}\right) \\
& +\left(\varepsilon_{i, n, t}-\tilde{\varepsilon}_{i, \mathrm{Rn}, t}\right)
\end{aligned}
$$

Recall that $P S_{i, m}$ is the amount of public spending by the municipality $m$ where $i$ is localized. $\tau_{m, t}$ is the local (municipal plus jurisdictional) local tax rate observed in the year of the transaction.

$S_{i} \times$ Tconst $_{i} \times \tau_{i, m, t}$ is introduced to proxy for the amount of real taxes paid by the owners of each house. This is the tax rate multiplied by a proxy for the base related to each house. This base is not available from our data, but it clearly depends on the size of the house and its period of construction. We present the estimated results of equation (13) in Table 5 for $d_{\max }$ equals to 1,000 in the first column and to 2,000 in column 2.

[Table 5 about here]

Recall that Tconst 1 takes the value 1 when the property was built before 1850 , Tconst 2 when it was built between 1850 and 1913, Tconst 3 between 1914 and 1947, Tconst4 between 1948 and 1969, Tconst5 between 1970 and 1980, Tconst 6 between 1981 and 1991. Tconst 7 takes the value 1 when the property was built after 1992 and is not new when the 
transaction occurs, Tconst 8 takes the value 1 when was built after 1992 and is new when the transaction occurs. Tconst 5 is the reference.

\begin{abstract}
Almost all the time dummies are significant and show that, all else being equal, the older the house, the more the tax rate weighted by size has a negative impact on the transaction price. This is true for houses built before 1991, just before the last updating of property bases. This result confirms that, in France, property tax matters for house prices, but it is necessary to take into account the fact that fiscal bases vary among transactions build at different period to observe the negative relationship.
\end{abstract}

\title{
6.2. Endogeneity
}

As described in the introduction, the Tiebout sorting effect implies that richer people have a preference for more public services, and leads to the fact that property prices and local public policies can be simultaneously determined. This means that property tax rate and the operating public spending may be endogenous; they also depend on local wealth and therefore on property prices. We test for potential endogeneity in both local variables. When local property taxation and/or public spending are endogenous, the IV method is used, as in Tables 6 and 7.

[Table 6 about here]

In Table 6, column (1) where public operating spending and the tax rate are both considered to be exogenous, this exogeneity is not rejected. In column (2), exogeneity is rejected only for operating spending. Detailed results of instrumental regressions, exogeneity tests and the weakness of instruments are available on request. The first step adjusted $\mathrm{R}^{2}$, the $\mathrm{F}$ test of instruments equals zero and the p. value of the exogeneity test are presented in appendix B, 
table 8 . It is instrumented by the housing tax rate $^{7}$ and the national government grant ("Dotation Globale de Fonctionnement"). ${ }^{8}$ and the local public capital expenditures. When regressing the instruments on the residual, they are all rejected at $10 \%$.

While the level of property tax rates influences the level of property prices, the housing tax rate does not. This outcome may be explained by the fact that owners do not pay the housing tax if they do not occupy the accommodation. In France, around half of the population rents its accommodation. Moreover, housing tax payment depends on the revenue of the occupier. Many categories of housing tax payers benefit from total tax exemptions or partial tax reductions. These reductions are strongly related to revenue and individual characteristics e.g. being elderly (aged over 60 years), having a handicap/disability, being a widow or widower, etc. Overall, more than one in two households (about 10 million households) benefits from a partial or total exemption.

Since local officials simultaneously consider both tax rates when setting rates, housing tax rates is a good instrument for property tax rates: the housing tax rate is correlated to the property tax rates (correlation coefficient is about $83 \%$, depending on data set) but not with property prices.

There are a number of national government grants in France. We used as instrument the basic grant ("dotation de base"), which depends on the size of the local population. ${ }^{9}$ This is computed as a lump sum grant for each inhabitant in the locality. This grant is therefore correlated to property tax rates, not to property prices.

Capital expenditures are exogenous to house prices, although operating expenditures are not. 
Operating expenditure accounts for some 60-80 per cent of overall municipal spending; capital expenditures can be financed from loans but operating spending cannot. Operating expenditure therefore depends directly on local revenues but capital expenditure does not.

The capital expenditures are also exogenous to house prices, even if operating expenditures are not. These operating spending accounts for about 60 to 80 per cent of overall municipal spending (see Foucault, Madies and Paty, 2008) and the capital expenditures can be financed by loan since operating spending can not. The operating expenditures therefore depend directly from local revenues when the capital ones do not. There are two other kinds of explanations for why municipal capital expenditure and housing prices in the same year are not statistically related.

The first is linked to the time lag between capital expenditure and its effect on the quantity and quality of local public services. There can be a large disconnect between construction period and putting into use. For example, construction of a tramway line incurs huge cost before the line comes into service, with the result that in the period of investment in this transport infrastructure housing prices are not correlated to capital expenditure in the same period. If the new tramway line is capitalized in house prices, this cannot be observed in one year, and the timing of major public capital spending is not the same as the timing or date when housing prices optimally capitalize the new public service. Capital expenditure unlike other public investment, does not have a one-shot effect.

The second reason is that a large part of local capital expenditure is financed by other levels of government, especially inter-municipality and regional levels. It should be noted that since the beginning of the 1990s, there has been constant introduction of laws reviving local cooperation in France. Based on the volunteering principle, neighbouring municipalities that desire to collectively finance and manage some public services can create an inter- 
municipality. This supra-municipal structure then co-exists with the municipal structure. Municipalities have transferred to inter-municipalities much of their expenditure in a bid to promote substantial economies of scale, including road building and maintenance, wastewater system, water supply... 95\% of French municipalities belong to an inter-municipality and this applies to both areas studied in this paper: Besançon and Dijon. For example, capital expenditure for the inter-municipality of "Grand Dijon" was about 60 million euros in 2010, whereas capital expenditures for the city of Dijon was 80 millions euros. Finally, regional government is a big investor. For example, investment spending for the region of "Bourgogne" (which includes Dijon) was about 400 million euros (for the whole region).

In Table 7, column (1), exogeneity is rejected only for the tax rate ( $\mathrm{p}$. value $=0.0038$ ). The first step adjusted $\mathrm{R}^{2}$, the $\mathrm{F}$ test of instruments equals zero and the p. value of the exogeneity test are presented in appendix $\mathrm{B}$, table 9. For some interaction terms exogeneity cannot be rejected, but all variables are considered endogenous for coherence. They are instrumented by the housing tax, the housing tax rate multiplied by the size and the period of the building, and the national government grant. When regressing the instruments on the residual, they are all rejected at $10 \%$.

In column (2), exogeneity is once again rejected (p.value=0.103) only for the property tax rate. For some interaction terms exogeneity cannot be rejected, but all variables are, once again, considered to be endogenous. They are instrumented by the housing tax, the housing tax rate multiplied by the size and the building period and the capital spending. When regressing the instruments on the residual, they are all rejected at $10 \%$.

[Table 7 about here] 
Let us first comment on the result associated with the local public spending, which is that it has a significant positive effect on house prices. This result seems to confirm the assumption that local public services may be positively capitalized in property prices, especially in less densely populated areas. We can see that the distance threshold affects this result.

The property tax rate alone never has a significant impact on the property prices (per square meter). When the maximum threshold is equal to 1,000 meters, only four periods of construction time, size and tax rate have a significant effect. These effects are coherent with the assumption that the amount of taxation is more important than the rate; the older the house is, the lower the impact of the tax rate multiplied by the size on the prices. This effect is larger for houses built between the two World Wars. Column 2 also shows that property tax rates seem not to have a significant impact on property prices, when considered alone. However, almost all interaction terms are significant; the newer and larger the house, the more the tax rate increases the house price. We can conclude that the house price capitalizes the local taxation, but the amount of taxes paid by the owner has a greater impact on their choice of house than the tax rate.

\section{Conclusion}

The aim of this paper was to provide empirical evidence on the impact of local taxation on property prices, controlling for the amount of local public spending, in two French urban areas: Dijon and Besançon, using data on property taxation and real estate transactions for the period 1994-2004. We used an empirical methodology that allowed us to compare sales in the same spatial environment and to control for endogeneity in local taxation and public spending. We found first that local public spending has almost no effect or a very small effect, 
on property prices. We also found that local property taxation does not have the expected negative impact on transaction prices. However, buyers are more sensitive to the amount of taxes they will have to pay than to the tax rate.

\section{References}

Black, S.E., 1999. Do better schools matter? Parental valuation of elementary education. Quaterly Journal of Economics 114, 578-599.

Bound, Jaeger and Baker, 1995. Problems with instrumental variables estimation when the correlation between the instruments and the endogeneous explanatory variable is weak, Journal of the American Statistical Association, 430 (90), 443-450.

Brueckner, J.K., 1979. Property values, local public expenditures and economic efficiency. Journal of Public Economics 11(2), 223-245.

Can, A., 1992. Specification and estimation of hedonic house price models. Regional Science and Urban Economics 22, 453-474.

Charlot, S., Paty, S. 2007. Market access effect and local tax setting: evidence from French panel data. Journal of Economic Geography 7, 247-263.

Chaudry-Shah, A.M., 1989. A Capitalization Approach to Fiscal Incidence at the Local Level. Land Economics 65(4), 359-337.

Cushing, B. J., 1984. Capitalization of Interjurisdictional Fiscal Differentials: An Alternative Approach. Journal of Urban Economics 15, 317-326.

Dupoirier, E., Foucault, M., François, A., Grossman, E., Sauger, N., 2006. Les déterminants politiques des subventions intra-gouvernementales. Une analyse de la dotation globale de fonctionnement perçue par les communes françaises. Working Paper, University of Paris 1. 
Duranton, G., Gobillon, L., Overman, H. G. 2007. Assessing the effects of local taxation using microgeographic data. mimeo LSE.

Edel, M., Sclar, E., 1974. Taxes, spending and property values: Supply adjustment in a Tiebout-Oates model. Journal of Political Economy 82, 941-954.

Fack, G., Grenet, J., 2010. When do better schools raise housing prices? Evidence from Paris public and private schools. Journal of Public Economics 94 1-2, 59-77.

Edel, M., Sclar, E., 1974. Taxes, spending and property values: Supply adjustmentin a Tiebout-Oates model. Journal of Political Economy 82, 941-954.

Epple, D., Zelenitz, A., Visscher, M., 1978. A search for testable implications of the Tiebout hypothesis. Journal of Political Economy 86, 405-425.

Follain, J., Malpezzi, S., 1981. The flights to the suburbs: Insights gained from an analysis of central city vs. suburban housing costs. Journal of Urban Economics 9, 381-398.

Foucault, M., Madies, T., Paty, S., 2008. Public spending interactions and local politics. Empirical evidence from French municipalities, Public Choice, 137(1), 57-80.

Gibbons, S., Machin, S., 2003. Valuing English primary schools. Journal of Urban Economics $53,197-219$.

Holmes, T. J., 1998. The Effect of State Policies on the Location of Manufacturing: Evidence from State Borders. Journal of Political Economy 106(4), 667-705.

Hamilton, B.W., 1975. Zoning and property taxation in a system of local governments. Urban Studies 12, 205-11.

King, A.J., 1977. Estimating property tax capitalization: A critical comment. Journal of Political Economy 85, 425-431.

Mercier, M., 2000. Pour une République territoriale : l'unité dans la diversité/ Rapport d'information au Sénat 447 tome 1 (1999-2000).

Oates, W.E., 1969. The effects of of property taxes and local public spending on property 
values: An empirical study of tax capitalization and the Tiebout Hypothesis. Journal of Political Economy 77, 957-971.

Oates, W.E., 1973. The effects of property taxes and local public spending on property values: A reply and further results. Journal of Political Economy 81, 1004-1008.

OECD, 1999. Taxing powers of state and local government, OECD Tax Policy Studies 1, Paris.

Rosen, S., 1974. Hedonic prices and implicit markets: Product differentiation in pure competition. Journal of Political Economy 82, 34-55.

Rosen, H., Fullerton, D., 1977. A note on local property tax rates, public benefits levels, and property values. Journal of Political Economy 85, 433-440.

Rosenthal, S., 1974. Hedonic prices and implicit markets: Product differentiation in pure competition. Journal of Political Economy 82, 34-55.

Sheppard, S., 1999. Hedonic analysis of housing markets. In: Cheshire, P., Mills, E. S., (Eds.). Handbook of Urban and Regional Economics, Vol. 3, Elsevier Science, 1595-1635.

Sonstelie, J., Portney, P., 1980. Gross rents and market values: Testing the implications of the Tiebout hypothesis. Journal of urban Economics 7, 102-118.

Starret, D. A., 1981. Land Value Capitalization in Local Public Finance. Journal of Political Economy 89, 306-327.

Stegarescu, D., 2004. Public sector decentralization: measurement concepts and recent international trends. ZEW Discussion Paper 04-74.

Tiebout, C.M., 1956. A pure theory of local expenditures. Journal of Political Economy 64, 416-424.

Wales, T.J., Wiens, E.G., 1974. Capitalization of residential property tax: An empirical study. Review of Economic statistics 56, 329-333.

Yinger, J., 1982. Capitalization and the Theory of Local Public Finance. Journal of Political 
Economy 90, 917-943.

\section{Appendix A: Econometric issues related to estimation of the hedonic model}

Considering capitalization into house values, Can (1992) distinguishes between two levels of externalities. The first captures the neighborhood effects, i.e. the impact of common neighborhood characteristics on housing prices. The second includes spatial spill-over effects - adjacency effects- such as the impact of prices of neighboring buildings on the price of a given property. These effects are not confined to jurisdictions, they can cross boundaries. As argued by Can (1992), locational effects require the use of different specifications for the housing price equation. The first includes neighborhood effects as direct determinants of house values. The resulting model is called the traditional hedonic specification:

$$
V=c+\zeta G-\tau t+{ }_{i=1}^{n} a_{i} Z_{i}+\eta N+\varepsilon
$$

where $N$ are neighborhood characteristics and $\varepsilon$ is a vector of i.i.d. error terms.

The second specification incorporates spatial heterogeneity. Neighborhoods are no longer treated as direct determinants of housing prices but as determinants of spatial drift in the structural parameters. This model is called the spatial expansion specification:

$$
V=c+\zeta G-\tau t+_{i=1}^{n}\left(a_{i O}+a_{k 1} N\right) Z_{i}+\varepsilon
$$

The next two specifications include both neighborhood effects and adjacence effects.

The traditional hedonic autoresgressive specification is as follows:

$$
V=c+\rho W V+\zeta G-\tau t+_{i=1}^{n} a_{i} Z_{i}+\eta N+\varepsilon
$$

where $W V$ is the spatially lagged dependent variable and $\rho$ its parameter. Finally the last 


$$
V=c+\rho W V+\zeta G-\tau t+_{i=1}^{n}\left(a_{i o}+a_{k 1} N\right) Z_{i}+\varepsilon
$$

Spatial effects are present in three out of four of these model specifications. In the spatial expansion specification, spatial heterogeneity is introduced in the form of varying-parameters. In the traditional hedonic autoregressive model, spatial dependence is included using the autoregressive form. Both spatial heterogeneity and dependence are incorporated in the final specification. Tests for spatial effects need to be run to detect the existence of spatial dependence and/or spatial heterogeneity and to choose the right specification.

\section{Appendix B: Results on the validity and the weakness of instruments}

As suggested by Bound, Jaeger and Baker (1995), we consider that the partial $\mathrm{R}^{2}$ and the Fisher test of instruments equals zero at the first-stage of IV regressions are good indicators of the quality of instruments. The following tables present them for IV estimates we have considered in section 6 .

[Table 8 here]

[Table 9 here] 


\footnotetext{
${ }^{1}$ The last major updating was in 1970 .

${ }^{2}$ Holmes (1999) also used the discontinuity border effect to test the impact of US state policies on local development.
}

${ }^{3}$ Municipal tax rates are voted on annually on the basis of predicted annual spending and the tax base. French local governments have great autonomy in their tax rate decisions and divide necessary expenditure by the tax base to get the tax rate.

${ }^{4}$ The property tax base is half of the property's theoretical rental value; the housing tax base is the whole value.

${ }^{5}$ Groups of localities (or EPCI) are not formal local governance structure since they are not compulsory and they do not apply to the whole territory. Localities can decide not to join these groups. However, where they exist, they have autonomy for setting tax rates using the same tax base as the other three levels (localities, counties and regions).

${ }^{6}$ Property tax rates and local public spending are not colinear. The Pearson correlation coefficient is equal to 0.39, when Dist.max=2,000, and it is equal to 0.59, when Dist.max=1,000.

${ }^{7}$ The housing tax is also based on property rental value and payable by the occupier.

${ }^{8}$ Local revenue sources also come from central government grants (23\%).

${ }^{9}$ However, it appears that the grant attribution criteria are very complicated (see Dupoirier et al. 2006). They are also based on multiple indicators such as geographical aspects (size, length of roads...), social features (average income, number of social houses..) and many others that may be positively or negatively linked to house prices. Because of this complexity, Dupoirier et al. show that there is there is wriggle room for public decision making in grant awards and that grants are correlated more to political features (political proximity to the national government). 


\section{Tables and figures}

Figure 1: Property prices per square meter

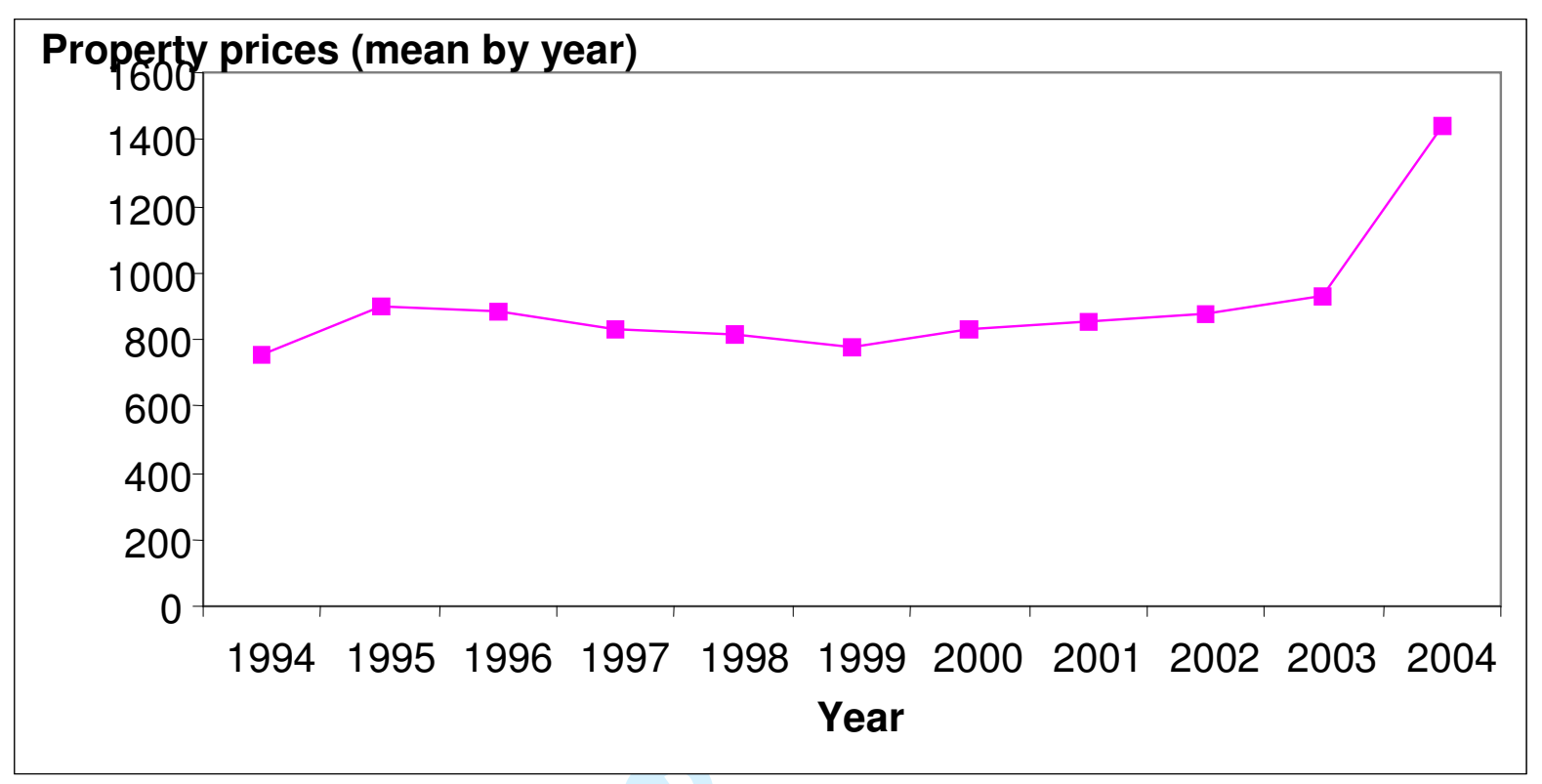

Figure 2: Property tax rate (\%)

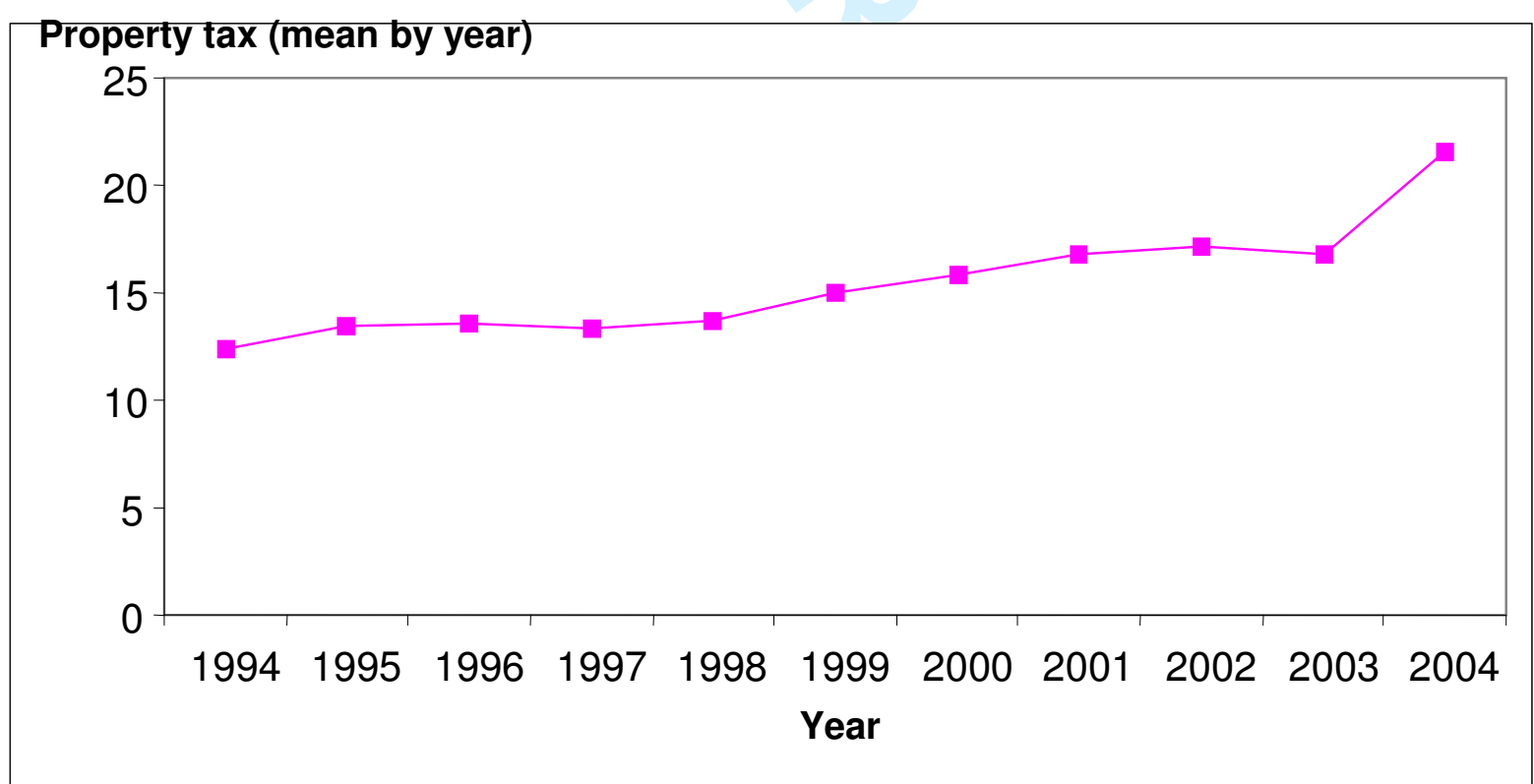

Figure 2: Property tax rate (\%) 


\begin{tabular}{|l|c|c|c|c|c|}
\hline Variable & $\mathrm{N}$ & \multicolumn{1}{|c|}{ Mean } & \multicolumn{1}{|c|}{ Std Dev Minimum } & Maximum \\
\hline Property tax (\%) & 13577 & 16.049 & 5.817 & 1.000 & 34.770 \\
\hline Prop. Prices (Euros psm) & 13577 & 873.172 & 566.217 & 0.213 & 4380.15 \\
\hline Living space (sm) & 10362 & 94.106 & 44.856 & 8.000 & 602.000 \\
\hline GardenSize & 10362 & 5.733 & 13.789 & 0.000 & 588.086 \\
\hline Rooms number & 10362 & 4.242 & 1.806 & 0.000 & 17.000 \\
\hline
\end{tabular}

Table 1: Descriptive statistics

Map 1: Property prices (square meter) in the urban areas of Dijon and Besançon
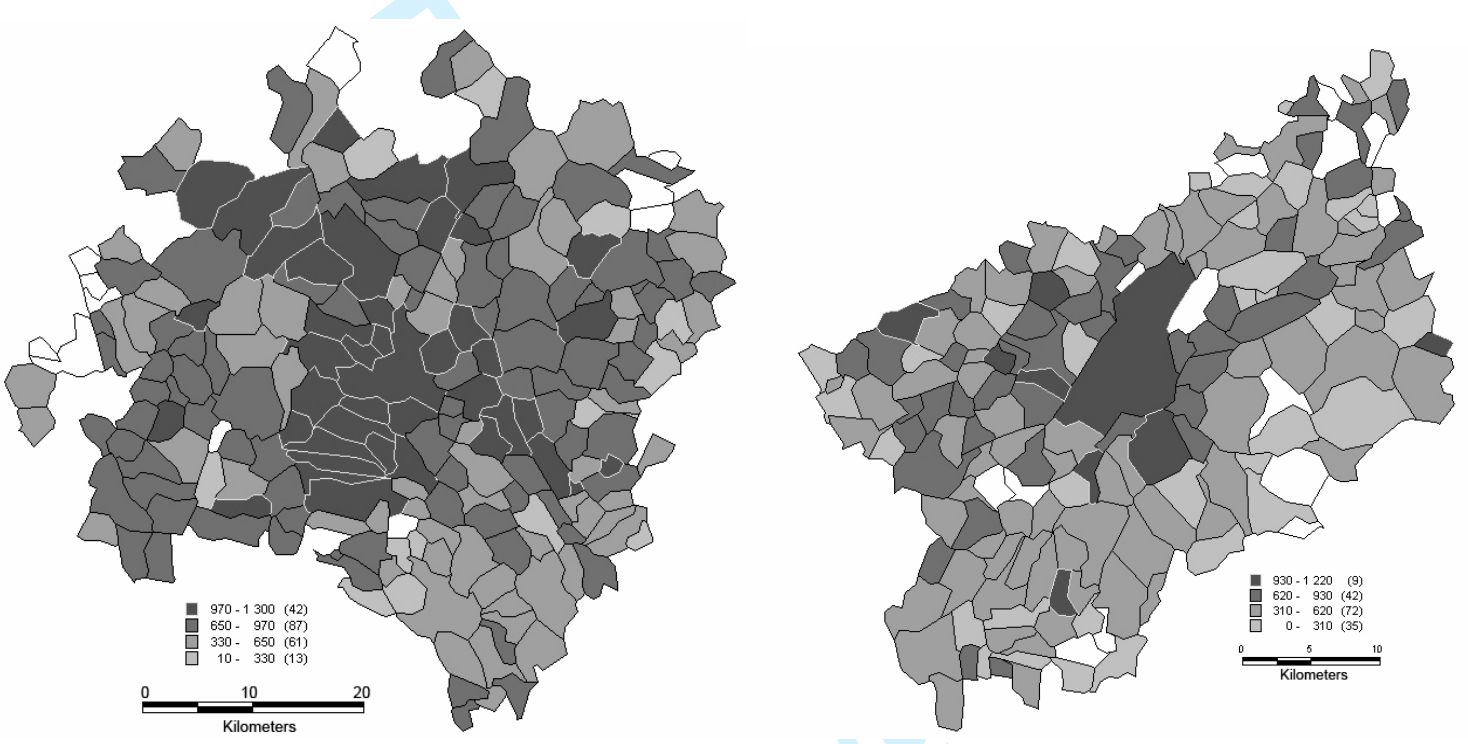

Map 2: Property tax rates in the urban areas of Dijon and Besançon
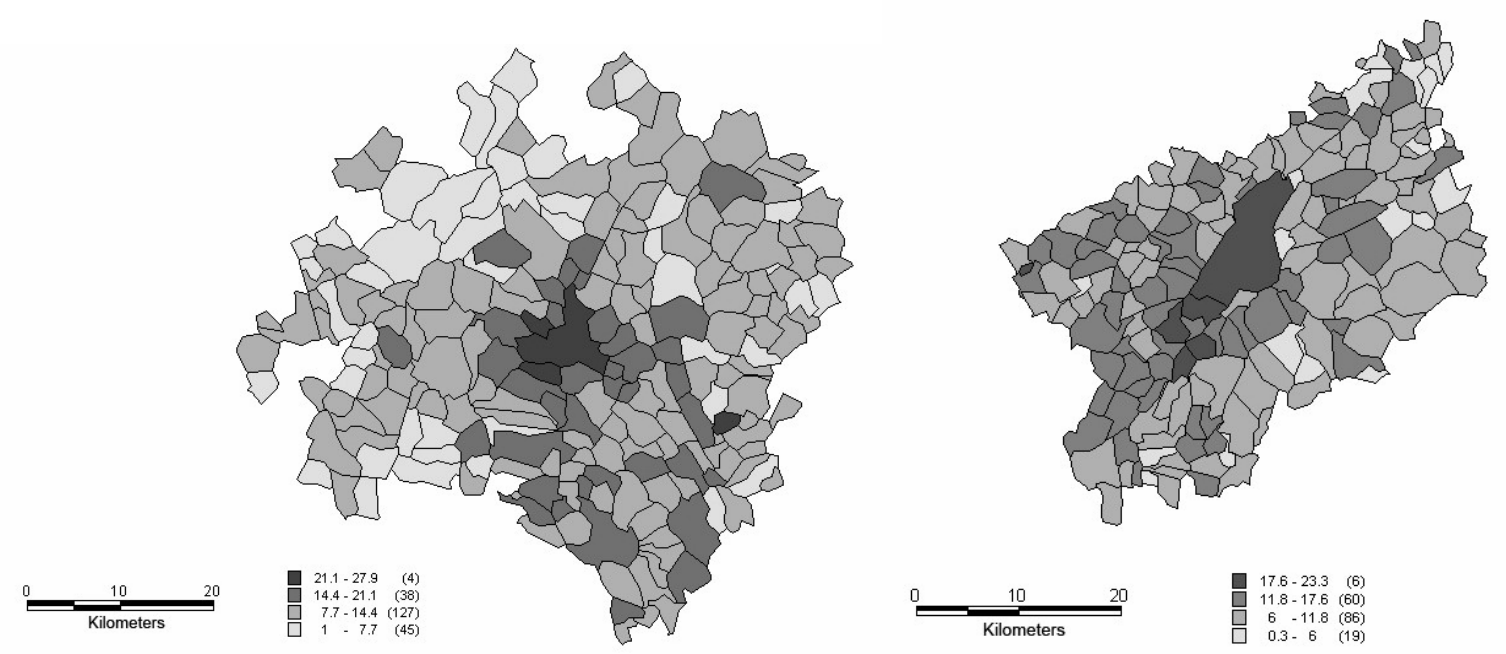
Map 3: Transaction location in the urban area of Dijon $(\mathrm{dmax}=2,000 \mathrm{~m})$

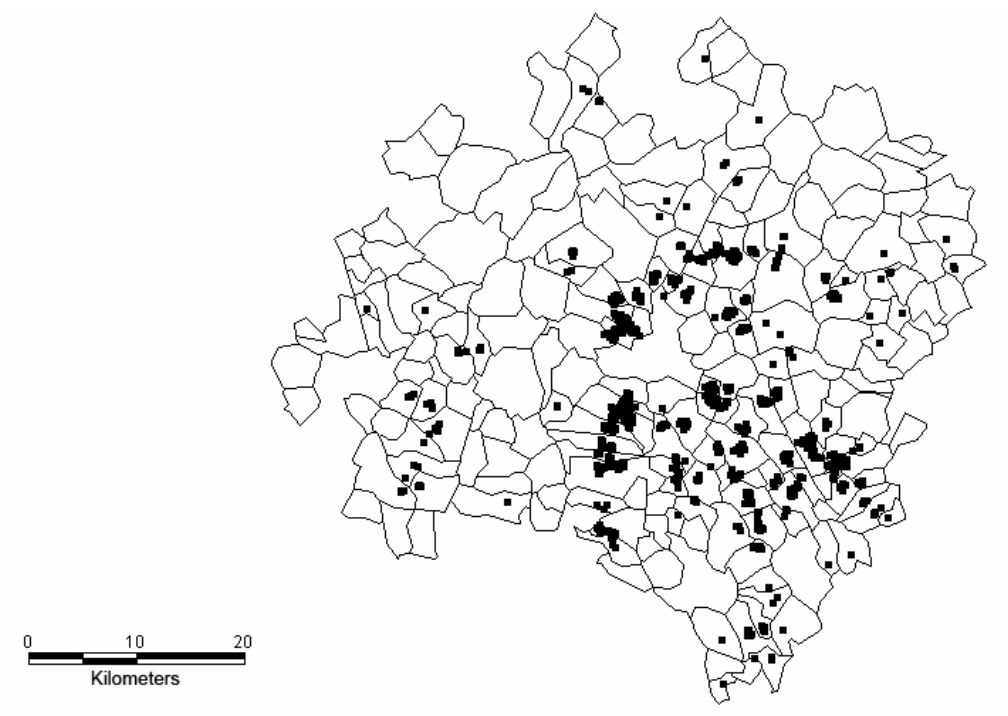

Map 4: Transaction location in the urban area of Besancon $(\mathrm{dmax}=2,000 \mathrm{~m})$

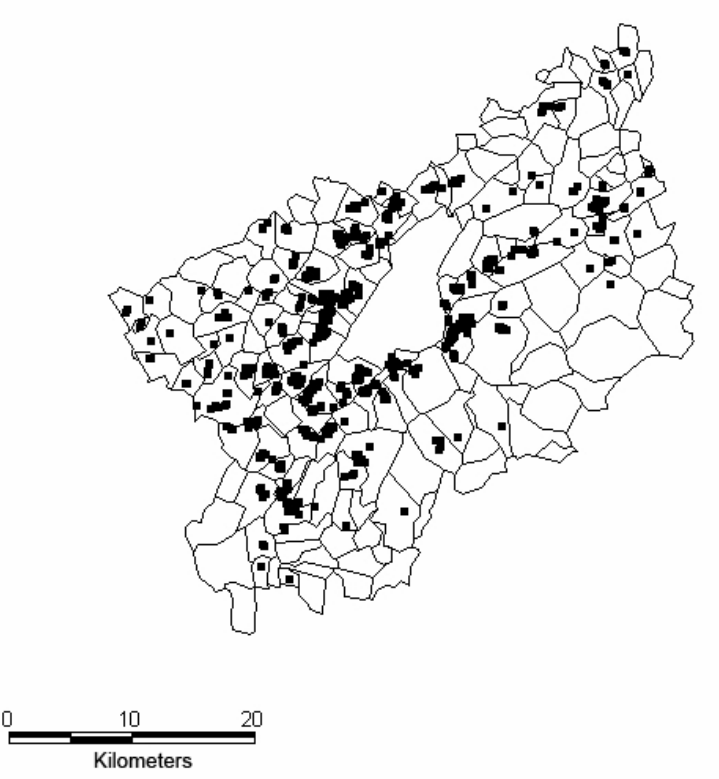


Table 2: Average (standard deviation) property tax rate in $\%$

\begin{tabular}{|l|c|c|c|}
\hline & \multicolumn{3}{|c|}{ Distance threshold } \\
\hline Urban area & $200 / 1000$ & $200 / 2000$ & None \\
\hline Number of municipalities & 80 & 226 & 361 \\
\hline Dijon & $16.45(5.20)$ & $13.98(4.75)$ & $17.36(5.76)$ \\
\hline Besançon & $12.24(2.70)$ & $12.41(3.55)$ & $16.15(5.64)$ \\
\hline Total & $15.36(5.03)$ & $13.44(4.44)$ & $16.90(5.74)$ \\
\hline
\end{tabular}


Table 3: Results of the hedonic model estimates

\begin{tabular}{|c|c|c|c|c|c|c|}
\hline & \multicolumn{2}{|c|}{ (1) } & \multicolumn{2}{|c|}{ (2) Dist. $\max =1,000$} & \multicolumn{2}{|c|}{ (3) Dist. $\max =2,000$} \\
\hline Estimation method & \multicolumn{2}{|c|}{ OLS } & \multicolumn{2}{|c|}{ OLS } & \multicolumn{2}{|c|}{ OLS } \\
\hline Size & $-0.00048 * * *$ & $(-5.86)$ & $-0.00185 * *$ & $(-5.00)$ & -0.00017 & $(-0.89)$ \\
\hline Number of rooms & $5.800 * * *$ & $(20.36)$ & $3.855 * *$ & $(2.79)$ & $8.902 * *$ & (11.95) \\
\hline Garden size & 0.000251 & $(0.96)$ & $0.0019 * *$ & $(3.77)$ & 0.00068 & $(1.67)$ \\
\hline Timeconst 1 & $-0.1507 * * *$ & $(-11.72)$ & $-0.349 * *$ & $(-4.77)$ & $-0.3401 * *$ & $(-10.74)$ \\
\hline Timeconst2 & $-0.1746 * * *$ & $(-14.92)$ & $-0.368 * *$ & $(-6.34)$ & $-0.2817 * *$ & $(-10.43)$ \\
\hline Timeconst3 & $-0.1032 * * *$ & $(-7.80)$ & $-0.328 * *$ & $(-4.99)$ & $-0.2896^{* *}$ & $(-7.20)$ \\
\hline Timeconst4 & $-0.0352 * * *$ & $(-3.65)$ & $-0.0953^{*}$ & $(-2.78)$ & $-0.0500 *$ & $(-2.23)$ \\
\hline Timeconst6 & $0.0997 * * *$ & $(9.68)$ & -0.0299 & $(-0.92)$ & $0.0591 * *$ & $(3.01)$ \\
\hline Timeconst7 & $0.1824 * * *$ & $(11.81)$ & 0.0474 & $(0.83)$ & $0.0898 * *$ & $(2.70)$ \\
\hline Timeconst8 & $0.2078 * * *$ & $(8.42)$ & 0.0747 & $(0.71)$ & 0.1014 & $(1.50)$ \\
\hline VAT & $-0.0067 * * *$ & $(-6.46)$ & -0.0049 & $(-1.39)$ & $-0.0049 *$ & $(-2.23)$ \\
\hline 1995 & -0.0320 & $(-1.58)$ & $-0.158^{*}$ & $(-2.96)$ & -0.0459 & $(-1.16)$ \\
\hline 1996 & -0.0162 & $(-0.87)$ & -0.086 & $(-1.94)$ & -0.0048 & $(-0.14)$ \\
\hline 1997 & $-0.0342 *$ & $(-1.95)$ & -0.0587 & $(-1.18)$ & -0.0417 & $(-1.30)$ \\
\hline 1998 & 0.0116 & $(0.72)$ & $-0.1455 * *$ & $(-3.15)$ & 0.0089 & $(0.32)$ \\
\hline 1999 & $-0.0444 * * *$ & $(-3.98)$ & $-0.0966^{*}$ & $(-2.36)$ & $-0.0795 * *$ & $(-3.47)$ \\
\hline 2001 & $0.0675 * * *$ & $(6.01)$ & 0.0131 & $(0.33)$ & 0.0412 & $(1.68)$ \\
\hline 2002 & $0.0952 * * *$ & $(7.90)$ & 0.0238 & $(0.46)$ & $0.0708^{*}$ & $(2.38)$ \\
\hline 2003 & $0.1647 * * *$ & $(14.29)$ & $0.1422 *$ & $(2.46)$ & $0.183 * *$ & $(6.80)$ \\
\hline 2004 & $0.3799 * * *$ & $(22.54)$ & 0.2815 & $(1.33)$ & $0.384 * *$ & $(3.64)$ \\
\hline Intercept & $6.710 * * *$ & $(6.71)$ & $7.122 * *$ & $(72.68)$ & $6.573 * *$ & $(126.67)$ \\
\hline $\operatorname{Adj} . \mathrm{R}^{2}$ & \multicolumn{2}{|c|}{0.2050} & \multicolumn{2}{|c|}{0.2156} & \multicolumn{2}{|c|}{0.2490} \\
\hline Number of obs. & \multicolumn{2}{|c|}{10,053} & \multicolumn{2}{|c|}{629} & \multicolumn{2}{|c|}{2,164} \\
\hline
\end{tabular}

Dependent variable: Observed sale price per square meter. $* *$ : significant at $1 \%, *$ : significant at $5 \%$. T-values in parentheses. 
Table 4: Results of the second step estimates in spatial differences with OLS

\begin{tabular}{|c|c|c|c|c|}
\hline Variables & \multicolumn{2}{|c|}{ (1) Dist. max $=1,000$} & \multicolumn{2}{c|}{ (2) Dist. max $=2,000$} \\
\hline Estimation method & \multicolumn{2}{|c|}{ OLS } & \multicolumn{2}{c|}{ OLS } \\
\hline Property tax rate & -0.00273 & $(-0.05)$ & $-0.05437 * *$ & $(-2.06)$ \\
\hline Local Public Spending & -0.01053 & $(-0.70)$ & 0.00473 & $(0.63)$ \\
\hline Adj. $\mathrm{R}^{2}$ & \multicolumn{2}{|c|}{0.000} & \multicolumn{2}{|c|}{0.0011} \\
\hline Number of obs. & \multicolumn{2}{|c|}{585} & \multicolumn{2}{|c|}{2082} \\
\hline
\end{tabular}

Dependent variable: spatial difference of estimated sale price per square meter. $* * *$ : significant at $1 \%, * *$ : significant at $5 \%$.
, *: significant at $10 \%$.T-values in parentheses.

Table 5: Results of the second step estimates in spatial differences with base proxy and OLS

\begin{tabular}{|c|c|c|c|c|}
\hline Variables & \multicolumn{2}{|c|}{ (1) Dist. max $=1,000$} & \multicolumn{2}{c|}{ (2) Dist. max $=2,000$} \\
\hline Estimation method & \multicolumn{2}{|c|}{ OLS } & \multicolumn{2}{c|}{ OLS } \\
\hline Property tax rate & 0.0454 & $(0.81)$ & 0.01532 & $(0.60)$ \\
\hline Local Public Spending & -0.0057 & $(-0.38)$ & $0.01354 *$ & $(1.84)$ \\
\hline Timeconst1*Size*tax rate & 0.000008 & $(0.29)$ & $-0.0000152 * * *$ & $(-9.97)$ \\
\hline Timeconst2*Size*tax rate & $-0.00009 * * *$ & $(-4.13)$ & $-0.0000096 * * *$ & $(-9.74)$ \\
\hline Timeconst3*Size*tax rate & $-0.00008^{* * *}$ & $(-2.92)$ & $-0.0000150 * * *$ & $(-5.02)$ \\
\hline Timeconst4*Size*tax rate & $-0.00002 * *$ & $(-2.24)$ & $-0.0000074 * * *$ & $(-4.45)$ \\
\hline Timeconst6*Size*tax rate & $0.00004 * * *$ & $(2.83)$ & $0.0000074 * * *$ & $(3.68)$ \\
\hline Timeconst7*Size*tax rate & 0.00001 & $(0.49)$ & -0.000010 & $(-1.29)$ \\
\hline Timeconst8*Size*tax rate & 0.00006 & $(1.04)$ & $0.0000258 * * *$ & $(2.62)$ \\
\hline Adj. $\mathrm{R}^{2}$ & 0.0700 & \multicolumn{3}{c|}{0.1079} \\
\hline Number of obs. & \multicolumn{5}{|c|}{585} & \multicolumn{3}{c|}{} \\
\hline
\end{tabular}

Dependent variable: spatial difference of estimated sale price per square meter. $* * *$ : significant at $1 \%, * *$ : significant at $5 \%$. , *: significant at $10 \%$.T-values in parentheses.

Table 6: Results of the second step estimates in spatial differences using the IV method

\begin{tabular}{|l|c|c|c|c|}
\hline Variables & \multicolumn{2}{|c|}{ (1) Dist. max $=1,000$} & (2) Dist. max $=2,000$ \\
\hline Estimation method & \multicolumn{2}{|c|}{ OLS } & \multicolumn{2}{c|}{ IV } \\
\hline Property tax rate & -0.00273 & $(-0.05)$ & -0.0042 & $(-0.45)$ \\
\hline Local Public Spending & -0.01053 & $(-0.70)$ & -0.0420 & $(-1.53)$ \\
\hline Adj. $\mathrm{R}^{2}$ & \multicolumn{2}{|c|}{0.000} & \multicolumn{2}{c|}{0.0010} \\
\hline Sargan p. value & 0.2648 & 0.8292 & \multicolumn{2}{|c|}{2082} \\
\hline Number of obs. & \multicolumn{2}{|c|}{585} & \multicolumn{3}{|c|}{} \\
\hline
\end{tabular}

Dependent variable: spatial difference of estimated sale price per square meter. $* * *$ : significant at $1 \%$, ** : significant at $5 \%$. *: significant at $10 \%$.T-values in parentheses.

Table 7: Results of the second step estimates in spatial differences using the IV method 
Dependent variable: spatial difference of estimated sale price per square meter. ***: significant at $1 \%$, **: significant at $5 \%$. *: significant at $10 \%$.T-values in parentheses.

\section{Table 8: Results of the first step estimates without tax base control}

\begin{tabular}{|l|l|l|l|}
\hline Endogenous variables & \multicolumn{3}{|l|}{ (2)Dist. $\max =2,000^{*}$} \\
\hline & Part. Ad. $\mathrm{R}^{2}$ & F. value & Exo. test \\
\hline Local Public Spending & 0.611 & 1092 & 0.1173 \\
\hline
\end{tabular}

Instruments: housing tax rate, national government grant ("Dotation Globale de Fonctionnement") and local public capital expenditures.

Table 9: Results of the first step estimates with tax base control 


\begin{tabular}{|r|c|c|c|c|c|c|}
\hline Endog. variables & \multicolumn{3}{|c|}{ (1) Dist. max=1,000 } & \multicolumn{3}{c|}{ (2) Dist. max=2,000 } \\
\hline & Part. Ad. R & F. value & Exo. test & Part. Ad. R & F. value & Exo. test \\
\hline Property tax rate & 0.62172 & 107 & 0.0066 & 0.52393 & 255 & 0.0461 \\
\hline Tconst1*Size*tax r. & 0.99315 & 9390 & 0 & 0.98264 & 13086 & 0.0002 \\
\hline Tconst2*Size*tax r. & 0.99414 & 10991 & 0.4146 & 0.97756 & 10070 & 0 \\
\hline Tconst3*Size*tax r. & 0.99400 & 10727 & 0.1592 & 0.99025 & 23481 & 0 \\
\hline Tconst4*Size*tax r. & 0.99772 & 28322 & 0.2988 & 0.99137 & 26545 & 0.0228 \\
\hline Tconst6*Size*tax r. & 0.98983 & 6306 & 0.5986 & 0.98809 & 19182 & 0.2311 \\
\hline Tconst7*Size*tax r. & 0.99267 & 8769 & 0.2905 & 0.98738 & 18087 & 0.6686 \\
\hline Tconst8*Size*tax r. & 0.99424 & 11184 & 0.2905 & 0.97559 & 9236 & 0.5244 \\
\hline Number of obs. & \multicolumn{5}{|c|}{585} & \multicolumn{4}{c|}{2082} & \\
\hline
\end{tabular}

Instruments: housing tax rate, housing tax rate multiplied by the size and the building period, and national government grant for (1) and local public capital expenditures for (2). 
